\title{
Awareness on Usage of Antiviral Group of Drugs Among Dental Students
}

\author{
Vinaya Swetha. $T^{1}$, Dhanraj Ganapathy ${ }^{2}$, Subhashree $\mathrm{R}^{3}$ and Rakshagan $\mathrm{V}^{4}$ \\ ${ }^{1}$ ASaveetha Dental College and Hospitals, Saveetha Institute of Medical \\ and Technical Sciences, Saveetha University, Chennai, India \\ ${ }^{2}$ Professor and Head of the Department,Department of Prosthodontics, Saveetha \\ Dental College and Hospitals,Saveetha Institute of Medical and Technical Sciences, \\ Saveetha University, Chennai, India \\ ${ }^{3}$ Senior Lecturer Department of Prosthodontics Saveetha Dental College and Hospitals Saveetha \\ Institute of Medical and Technical Sciences Saveetha University Chennai -77 India \\ ${ }^{4}$ Senior Lecturer Department of Prosthodontics Saveetha Dental College and Hospitals Saveetha \\ Institute of Medical and Technical Sciences Saveetha University Chennai -77, India
}

\section{ABSTRACT}

Members of the human herpesvirus (HHV) and human papillomavirus (HPV) families cause the most common primary viral infections of the oral cavity. Acyclovir is an antiviral drug that is primarily used for the treatment of HSV (herpes simplex virus) infection. It has higher activity towards both HSV-1 and HSV-2 as compared to the latter viral infections. Acyclovir remains the drug of choice for prophylaxis and treatment of HSV infection and is available in numerous forms such as tablet, suspension, intravenous injection, and ophthalmic ointment. The aim of the study is to determine the awareness of usage of antiviral groups of drugs among dental students. It is an online based questionnaire study in which 10 questions were circulated through an online forum through google forms and results were analysed using SPSS. In this study it is observed that about $63 \%$ of the dental students say that herpes is the most common virus they encounter in their dental environment. $68 \%$ of them say that herpes labialis is the common viral infection they commonly encounter in their dental environment. 45\% say that they use acyclovir as the first line of antiviral drug. Nearly 52\% of the dental students are aware of antiviral groups of drugs used in dentistry and still $47 \%$ of them are unaware of the antiviral drugs. Hence, it is important to create awareness among dental students.

KEY WORDS: ANTIVIRAL DRUGS, HERPES SIMPLEX VIRUS, HERPES LABIALIS, ACYCLOVIR, VALACYCLOVIR.

\section{ARTICLE INFORMATION}

*Corresponding Author: dhanraj@saveetha.com

Received 13th June 2020 Accepted after revision 8th August 2020

Print ISSN: 0974-6455 Online ISSN: 2321-4007 CODEN: BBRCBA

Thomson Reuters ISI Web of Science Clarivate Analytics USA and Crossref Indexed Journal

$$
1 \text { Clarivate }{ }_{\text {Analytics }} \text { crossef }
$$

NAAS Journal Score 2020 (4.31) SJIF: 2020 (7.728)

A Society of Science and Nature Publication,

Bhopal India 2020. All rights reserved.

Online Contents Available at: http//www.bbrc.in/

Doi: http://dx.doi.org/10.21786/bbrc/13.7/3 


\section{INTRODUCTION}

Antiviral drugs are a group of medications used for treating viral infections. Most antivirals target specific viruses, while a broad spectrum antiviral is effective against a wide range of viruses. Unlike antibiotics, antiviral drugs do not destroy their target pathogen, instead they prevent their development. Antiviral drugs are a class of antimicrobials, which also includes antibiotic, antifungal and antiparasitic drugs, antiviral drugs. Most antivirals are considered relatively harmless to the host, and therefore can be used to treat infections. Most common viruses in the dental environment are human herpes virus and human papillomavirus.

Herpes simplex virus 1 (HSV 1) and Herpes simplex virus 2 (HSV 2) which are DNA viruses of Herpesviridae family are the causative agent of HSV infections. These viruses infect both orofacial and pubic areas, HSV-1 affects the orofacial region while HSV-2 affects the pubic region(Azodo and Umoh, 2015). Herpes labialis is the most common orofacial form of recurrent HSV infection. It is a common worldwide affliction on which neither public health procedures, vaccines, nor antiviral chemotherapy have had a significant clinical impact('172 The natural history of experimental ultraviolet radiation(UVR)-induced herpes labialis, a human model of recurrent herpes simplex virus infection: Clinical, virologic and serologic observations following multiple exposures', 1993). Herpes labialis is a benign infective condition associated with the formation of vesiculo ulcerative lesions around the mouth which is often preceded by prodromal symptoms including pain, tingling and burning sensation(Capodiferro, 2019).

Risk factors such as ultraviolet light of both natural and artificial sources as in sunlight and tanning beds, lip chapping, lip trauma or abrasion, fever, physical and emotional stress(Jensen, Hoehns and Squires, 2004; Ensor, 2005; Marques-Silva et al., 2007). The diagnosis of herpes labialis is based on case history clinical appearance and the site of the lesions in immunocompetent patients while confirmatory laboratory diagnosis such as viral culture, polymerase chain reaction, serology, can be taken in immunocompromised patients(Arduino and Porter, 2007).

Acyclovir and valacyclovir are purine nucleoside analogues and both drugs act against herpes simplex 1 and 2. Neither acyclovir nor valacyclovir cures infection, but they decrease the symptoms associated with the viral infection. Both the drugs impair viral growth by inhibiting replication of the viral DNA(Margolis et al., 2007). The virus infected cells absorb more drugs compared to normal cells. Nausea, vomiting, and diarrhea can occur with both drugs. Patients on acyclovir should avoid acyclovir with amphotericin B. Valacyclovir should not be prescribed with SSRIs. Famciclovir is a pregnancy category B antiviral drug that is active against the herpes viruses('Antivirals Commonly Used in Dentistry: Assessment, Analysis, and Associated Dental Management Guidelines', 2017).
Other medications such as analgesics and antibiotics are the most common self medicated drugs among dental healthcare providers which help to control the associated pain and prevent secondary bacterial infection(Kalyan et al., 2013; Honore et al., 2020). The use of lubricant will help in decreasing discomfort associated with the condition and also helpful in preventing perioral scarring which is a rare complication of herpes labialis(Bose, 2007; Öztekin and Öztekin, 2019). Pediatricians are more familiar with antiviral drugs and provided with specific recommendations for treatment of viral infections. These drugs include acyclovir, amantadine, trisodium phosphonoformate, ganciclovir, ribavirin (Balfour, 1989).

Figure 1: Bar chart depicting the awareness about antiviral groups of drugs in the dental environment of the participants. Shows $52.5 \%$ of the students were aware about the usage of an antiviral group of drugs, 47\% of them are not aware about its usage

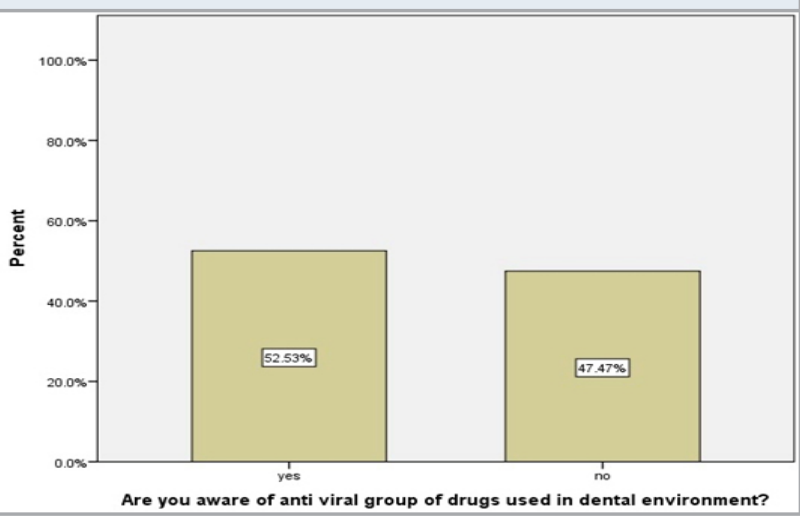

Figure 2: Bar chart depicting the awareness of the participants about herpes virus in the dental environment. Shows $61.6 \%$ of them are aware that the herpes virus is the most common virus seen in the dental environment and $38.3 \%$ disagree with it

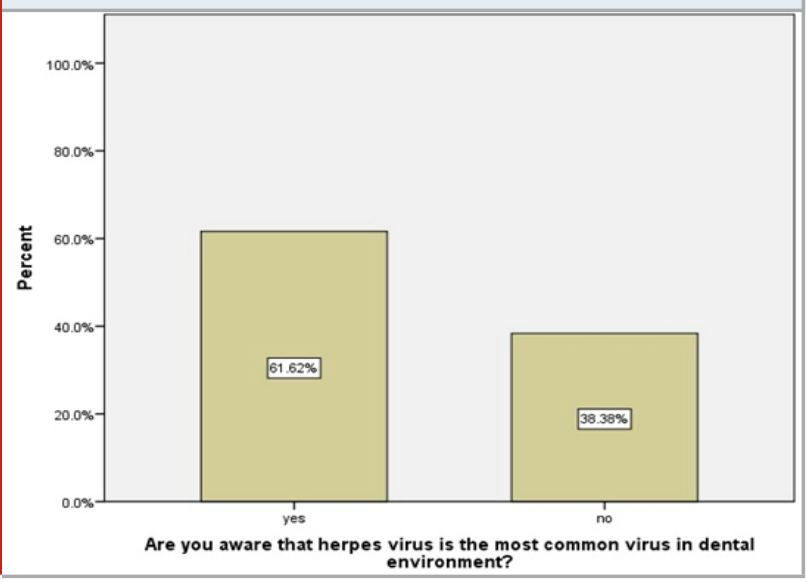

MATERIAL AND METHODS

It is a descriptive cross sectional study it includes 10 questions circulated among 100 population of dental students in chennai and the response was collected 
through google forms and the data was analysed statistically and the result was obtained. Analysis software used was SPSS.

Figure 3: Bar chart depicting that awareness of the participants about acyclovir drug against herpes labialis. Shows $66.6 \%$ of them are aware that acyclovir provides better cure for herpes labialis and 33\% of them disagree with it.

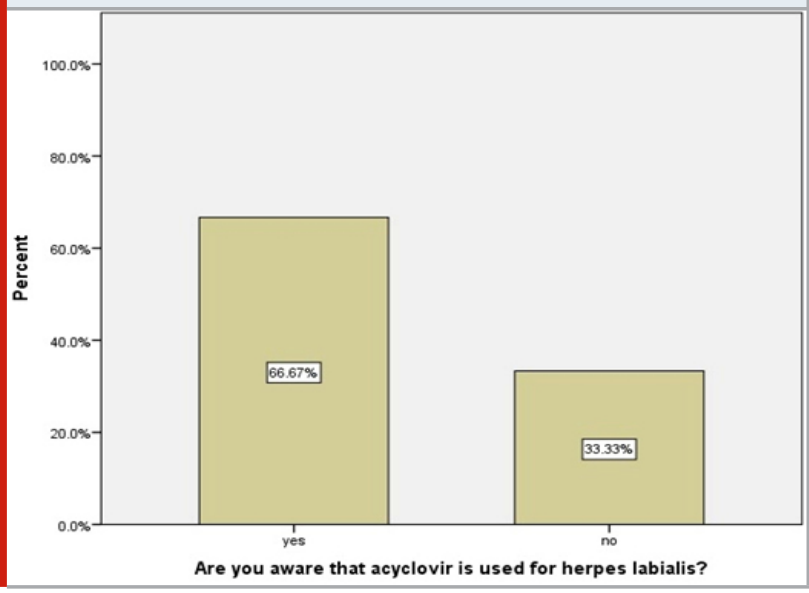

Data collection: An online platform known as survey planet was used. The questionnaire was uploaded on this site and the data was verified by an external viewer. Data was reported to excel and later exported to SPSS for analysis. The results were analysed and the responses were tabulated in the form of bar charts.

\section{RESULTS AND DISCUSSION}

By the results tabulated, it is seen that the level of awareness and knowledge about antiviral groups of drugs among dental students is good. In this study 17\% 2nd year undergraduate, 30\% 3rd year undergraduate, 35\% final year undergraduate, $17 \%$ intern undergraduate were participated. In this study $52.5 \%$ of the students were aware about the usage of an antiviral group of drugs, $47 \%$ of them are not aware about its usage (figure 1). About $61.6 \%$ of them are aware that the herpes virus is the most common virus seen in the dental environment and 38.3\% disagree with it (figure 2). About 62.6\% of them are aware that antiviral drugs are effective against herpes simplex 1 and 37\% of them are not aware of it. This study shows about 65\% of them are aware that HSV1 is the etiological agent for herpes labialis and 34\% of them are not aware of it. About 64.6\% of them agree that herpes is contagious, $35 \%$ of them disagree with it. In this study $72.7 \%$ of them say that the most common site for herpes labialis is lip, 22\% say that the common site for herpes labialis is buccal mucosa, and 5\% say that the common site for herpes labialis is tongue.

In this study $66.6 \%$ of them are aware that acyclovir provides better cure for herpes labialis and 33\% of them disagree with it (figure 3). About 44\% say that acyclovir is the most common drug used in dentistry, 20\% say that valacyclovir is the common drug used in dentistry (figure 4). Third year undergraduates are more aware of antiviral groups of drugs used in dentistry, final year and intern undergraduates are not aware of all antiviral drugs in dentistry (figure 5). Third year undergraduates are more aware that herpes labialis is the common oral viral infection followed by final year undergraduates (figure 6). Higher numbers of the third year undergraduates say that acyclovir is the most commonly used drug in dentistry, higher numbers of the final year undergraduates say that both acyclovir and valacyclovir are the commonly used drugs in dentistry (figure 7).

Figure 4: Bar chart depicting the distribution of the participants about common antiviral drugs used in dentistry. $44 \%$ say that acyclovir is the most common drug used in dentistry, 20\% say that valacyclovir is the common drug used in dentistry

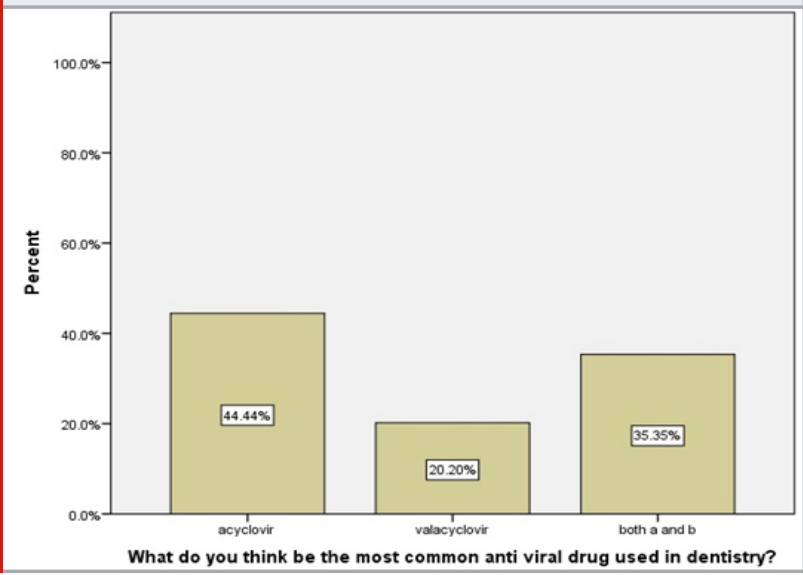

Figure 5: Bar chart represents the association of awareness of antiviral drugs and year of the study. Where the blue colour denotes 2 nd year undergraduates, green colour denotes 3rd year undergraduates and cream colour denotes final year undergraduates and violet colour denotes intern undergraduates. The $\mathrm{X}$ axis represents the question "Are you aware of antiviral groups of drugs used in dental environments?" and the $\mathrm{Y}$ axis represents the year of study. Third year undergraduates are more aware of antiviral groups of drugs used in dentistry, final year and intern undergraduates are not aware of all antiviral drugs in dentistry. Pearson chi square value $=63.483$, $\mathrm{p}=0.00<0.05$, significant association.

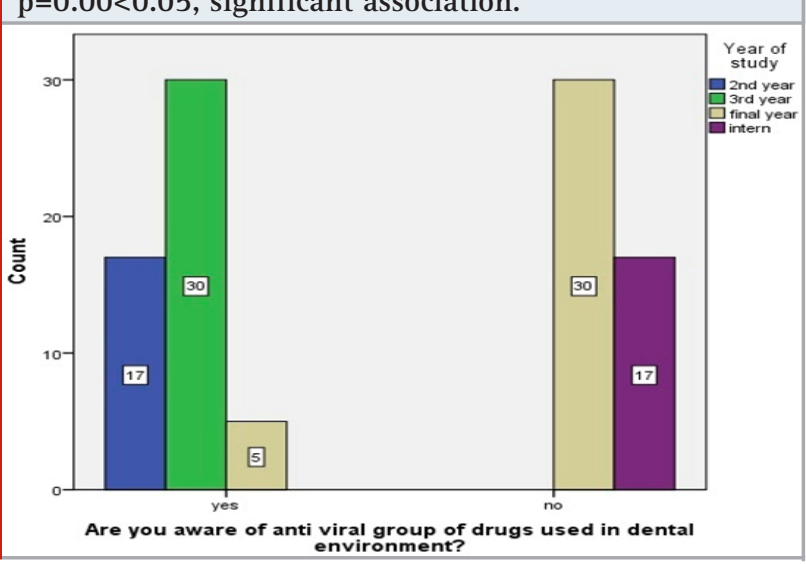


Previously our department has published extensive research on various aspects of prosthetic dentistry ('Evaluation of Corrosive Behavior of Four Nickelchromium Alloys in Artificial Saliva by Cyclic Polarization Test:An in vitro Study', 2017; Ganapathy, Kannan and Venugopalan, 2017; Jain, 2017a, 2017b; Ranganathan, Ganapathy and Jain, 2017; Ariga et al., 2018; Gupta, Ariga and Deogade, 2018; Anbu et al., 2019; Ashok and Ganapathy, 2019; Duraisamy et al., 2019; Varghese, Ramesh and Veeraiyan, 2019), this vast research experience has inspired us to research awareness and knowledge about usage of antiviral group of drugs among dental students.

Figure 6: Bar chart represents the association of awareness of herpes labialis and year of study. Where the blue colour denotes 2nd year undergraduates, green colour denotes 3rd year undergraduates and cream colour denotes final year undergraduates and violet colour denotes intern undergraduates. The $\mathrm{X}$ axis represents the question "Are you aware that herpes labialis is the most common oral viral infection?" and the $\mathrm{Y}$ axis represents the year of study. Third year undergraduates are more aware that herpes labialis is the common oral viral infection followed by final year undergraduates. Pearson chi square value $=$ 59.817, $\mathrm{p}=0.00<0.05$, significant association.

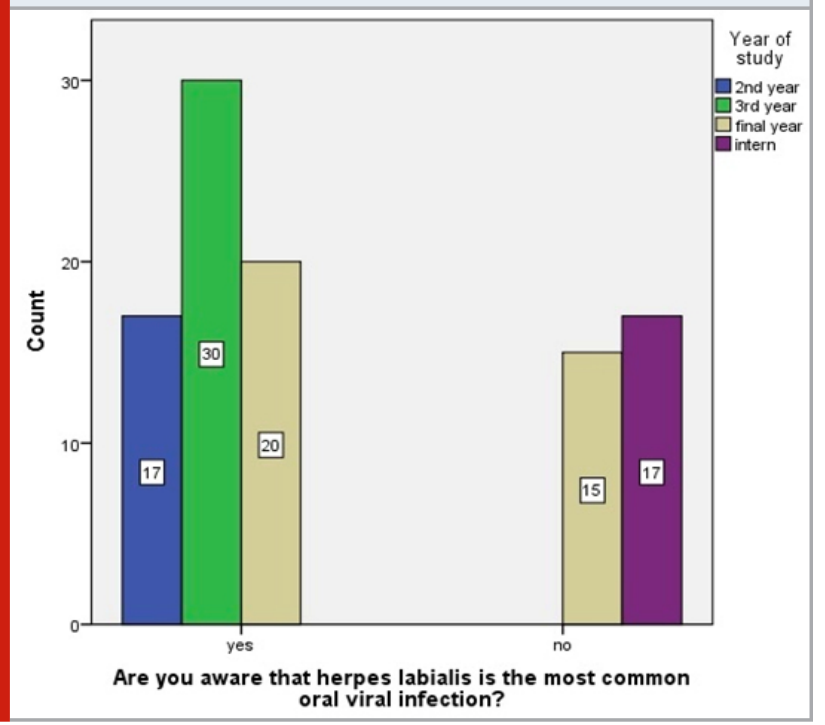

In this study $61.6 \%$ of the participants are aware that herpes virus is the most common virus in the dental environment. In the study of(Tabery, 2010), says that herpes simplex virus is the common virus they encounter in their dental environment. The study of(Dreno, Malkin and Saiag, 2013), also says that herpes virus is the common virus they encounter commonly in dentistry. Thus overall consensus of the study agrees with most of the articles.

In this study $66.6 \%$ of the participants stated that acyclovir provides better cure for herpes infection. The study(Rooney, 1993), says that they prescribe acyclovir as their first line of drug for herpes infection as it aids in quicker relief. In the study of(Beutner, 1992), they say they prefer acyclovir for herpes as it helps in decreasing the lesion caused by herpes infection. Thus overall consensus of the study agrees with most of the articles. In this study $44 \%$ of the participants commonly use acyclovir as their first line of drug for oral viral infections. In the study of(Tallury, Alimohammadi and Kalachandra, 2007), it says that acyclovir is the most commonly used drug in dentistry for oral viral infections. Overall consensus agrees with most of the articles.

The study(Spruance, J. c. B. Stewart, et al., 1990; Spruance, J. C. B. Stewart, et al., 1990), shows the observation with both ACV cream and penciclovir cream that efficacy occurs independently of the lesion stage at the initial treatment is paradoxical. It is intuitive that interruption of virus replication prior to the development of major pathological processes in the epidermis would be more likely to preserve the skin from virus induced damage and abbreviate the lesion course than application of treatment at a later stage. This concept received support from two prior clinical trials with peroral ACV and topical idoxuridine in dimethyl sulfoxide which showed that antiviral nucleoside efficacy was limited to the patients who initiated treatment in the prodrome or erythema lesion stage.

Figure 7: Bar chart represents the association of commonly used antiviral drug and year of study. Where the blue colour denotes 2nd year undergraduates, green colour denotes 3rd year undergraduates and cream colour denotes final year undergraduates and violet colour denotes intern undergraduates. The $\mathrm{X}$ axis represents the question "What do you think is the most common antiviral drug used in dentistry?" and the Y axis represents the year of study. Higher numbers of the third year undergraduates say that acyclovir is the most commonly used drug in dentistry, higher numbers of the final year undergraduates say that both acyclovir and valacyclovir are the commonly used drugs in dentistry. Pearson chi square value $=110.553$, $\mathrm{p}=0.00<0.05$, significant association.

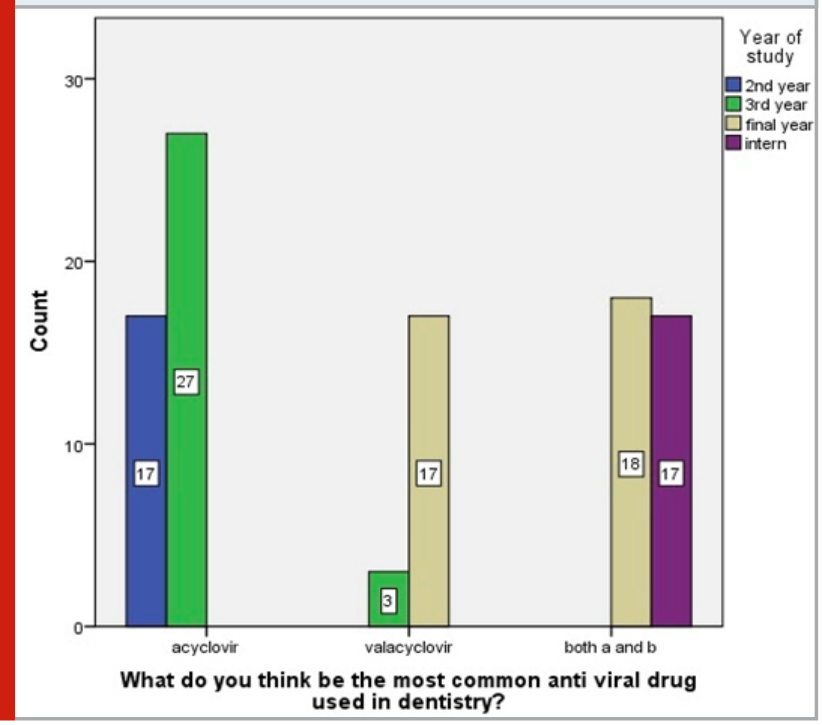


The study(Nilsen et al., 1982), says although formation of new lesions is very rare in herpes labialis, it was observed that topical acyclovir had no effect on new lesions, as local applications were limited to the expected site for the initial lesions, it serves as a one disadvantages of topical treatment. This use of topical treatment will also be limited in patients with multiple lesions at different sites, lesions in inaccessible places. Oral acyclovir is effective for recurrent mucocutaneous herpes simplex infections at other sides, and studies evaluating the prophylactic use of oral acyclovir for frequent recurrences of herpes labialis and genital herpes are currently in progress.

\section{CONCLUSION}

In this study it shows, nearly 52\% of the dental students are aware of antiviral groups of drugs used in dentistry and still $47 \%$ of them are unaware of the antiviral drugs. About $44 \%$ of the dental students say acyclovir is the most commonly used drug in dentistry followed by valacyclovir(20\%). Hence, it is important to create awareness among dental students about other classes of antiviral drugs for providing them better treatment.

ACKNOWLEDGEMENTS: Nil.

\section{Conflict of Interest: None Declared.}

\section{REFERENCES}

'172 The natural history of experimental ultraviolet radiation(UVR)-induced herpes labialis, a human model of recurrent herpes simplex virus infection: Clinical, virologic and serologic observations following multiple exposures' (1993) Antiviral Research, p. 135. doi: 10.1016/0166-3542(93)90550-3.

Anbu, R. T. et al. (2019) 'Comparison of the Efficacy of Three Different Bone Regeneration Materials: An Animal Study', European journal of dentistry, 13(1), pp. 22-28.

Antivirals Commonly Used in Dentistry: Assessment, Analysis, and Associated Dental Management Guidelines' (2017) Dentist's Guide to Medical Conditions, Medications, and Complications, pp. 155-158. doi: 10.1002/9781119421450.ch8.

Arduino, P. G. and Porter, S. R. (2007) 'Herpes Simplex Virus Type 1 infection: overview on relevant clinico-pathological features*, Journal of Oral Pathology \& Medicine, pp. 107-121. doi: 10.1111/j.16000714.2007.00586.x.

Ariga, P. et al. (2018) 'Determination of Correlation of Width of Maxillary Anterior Teeth using Extraoral and Intraoral Factors in Indian Population: A Systematic Review', World Journal of Dentistry, 9(1), pp. 68-75.

Ashok, V. and Ganapathy, D. (2019) 'A geometrical method to classify face forms', Journal of oral biology and craniofacial research, 9(3), pp. 232-235.

Azodo, C. C. and Umoh, A. 0. (2015) 'Herpes labialis among dental healthcare providers in Nigeria', Indian
Journal of Dentistry, p. 116. doi: 10.4103/0975962x.158186.

Balfour, H. H. (1989) 'Antiviral Drugs in Pediatrics', Archives of Pediatrics \& Adolescent Medicine, p. 1307. doi: 10.1001/archpedi.1989.02150230065025.

Beutner, K. R. (1992) 'Rational use of acyclovir in the treatment of mucocutaneous herpes simplex virus and varicella zoster virus infections', Seminars in dermatology, 11(3), pp. 256-260.

Bose, S. K. (2007) 'Herpes simplex virus in association with lip leucoderma', The Journal of Dermatology, pp. 280-281. doi: 10.1111/j.1346-8138.2007.00272.x.

Capodiferro, S. (2019) 'Comment on "efficacy of lowlevel laser therapy in management of recurrent herpes labialis: a systematic review", Lasers in Medical Science, pp. 841-841. doi: 10.1007/s10103-018-2592-8.

Dreno, B., Malkin, J.-E. and Saiag, P. (2013) 'Understanding recurrent herpes labialis management and impact on patients' quality of life: the HERPESCOPE study', European Journal of Dermatology, pp. 491-499. doi: 10.1684/ejd.2013.2072.

Duraisamy, R. et al. (2019) 'Compatibility of Nonoriginal Abutments With Implants: Evaluation of Microgap at the Implant-Abutment Interface, With Original and Nonoriginal Abutments', Implant dentistry, 28(3), pp. 289-295.

Ensor, D. (2005) 'The Significance of Herpes Simplex for School Nurses', The Journal of School Nursing, pp. 10-16. doi: 10.1177/10598405050210010401.

Evaluation of Corrosive Behavior of Four Nickelchromium Alloys in Artificial Saliva by Cyclic Polarization Test:An in vitro Study' (2017) World Journal of Dentistry, 8(6), pp. 477-482.

Ganapathy, D. M., Kannan, A. and Venugopalan, S. (2017) 'Effect of Coated Surfaces influencing Screw Loosening in Implants: A Systematic Review and Meta-analysis', World Journal of Dentistry, 8(6), pp. 496-502.

Gupta, P., Ariga, P. and Deogade, S. C. (2018) 'Effect of Monopoly-coating Agent on the Surface Roughness of a Tissue Conditioner Subjected to Cleansing and Disinfection: A Contact Profilometric Study', Contemporary clinical dentistry, 9(Suppl 1), pp. S122S126.

Honore, P. M. et al. (2020) 'Acyclovir for ventilatorassociated pneumonia refractory to antibiotics and with high viral herpes simplex load: we are not sure', Critical care / the Society of Critical Care Medicine, p. 262.

Jain, A. R. (2017a) 'Clinical and Functional Outcomes of Implant Prostheses in Fibula Free Flaps', World Journal of Dentistry, 8(3), pp. 171-176.

Jain, A. R. (2017b) 'Prevalence of Partial Edentulousness and Treatment needs in Rural Population of South India', World Journal of Dentistry, 8(3), pp. 213-217. Jensen, L. A., Hoehns, J. D. and Squires, C. L. (2004) ‘Oral 
Antivirals for the Acute Treatment of Recurrent Herpes Labialis', Annals of Pharmacotherapy, pp. 705-709. doi: 10.1345/aph.1d285.

Kalyan, V. et al. (2013) 'Evaluation of self-medication practices among undergraduate dental students of tertiary care teaching dental hospital in South India', Journal of Education and Ethics in Dentistry, p. 21. doi: 10.4103/0974-7761.126939.

Margolis, T. P. et al. (2007) 'Herpes Simplex Virus Type 2 (HSV-2) Establishes Latent Infection in a Different Population of Ganglionic Neurons than HSV-1: Role of Latency-Associated Transcripts', Journal of Virology, pp. 1872-1878. doi: 10.1128/jvi.02110-06.

Marques-Silva, L. et al. (2007) 'The Impact of Dental Surgery on HSV-1 Reactivation in the Oral Mucosa of Seropositive Patients', Journal of Oral and Maxillofacial Surgery, pp. 2269-2272. doi: 10.1016/j. joms.2007.05.029.

Nilsen, A. et al. (1982) 'EFFICACY OF ORAL ACYCLOVIR IN THE TREATMENT OF INITIAL AND RECURRENT GENITAL HERPES', The Lancet, pp. 571-573. doi: 10.1016/s0140-6736(82)90658-4.

Öztekin, A. and Öztekin, C. (2019) 'Vitamin D Levels in Patients with Recurrent Herpes Labialis', Viral Immunology, pp. 258-262. doi: 10.1089/ vim.2019.0013.

Ranganathan, H., Ganapathy, D. M. and Jain, A. R. (2017) 'Cervical and Incisal Marginal Discrepancy in Ceramic Laminate Veneering Materials: A SEM Analysis', Contemporary clinical dentistry, 8(2), pp. 272-278.

Rooney, J. F. (1993) 'Oral Acyclovir To Suppress
Frequently Recurrent Herpes Labialis: A Double-Blind, Placebo-Controlled Trial', Annals of Internal Medicine, p. 268. doi: 10.7326/0003-4819-118-4-19930215000004.

Spruance, S. L., Stewart, J. c. B., et al. (1990) 'Early Application of Topical 15\% Idoxuridine in Dimethyl Sulfoxide Shortens the Course of Herpes Simplex Labialis: A Multicenter Placebo-Controlled Trial', Journal of Infectious Diseases, pp. 191-197. doi: 10.1093/infdis/161.2.191.

Spruance, S. L., Stewart, J. C. B., et al. (1990) 'Treatment of Recurrent Herpes Simplex Labialis with Oral Acyclovir', Journal of Infectious Diseases, pp. 185-190. doi: 10.1093/infdis/161.2.185.

Tabery, H. M. (2010) 'Complications, Accompanying Signs, Recurrences, and Long-Term Sequelae of Herpes Simplex Virus Epithelial Keratitis', Herpes Simplex Virus Epithelial Keratitis, pp. 35-53. doi: 10.1007/978-3-64201012-5_3.

Tallury, P., Alimohammadi, N. and Kalachandra, S. (2007) 'Poly(ethylene-co-vinyl acetate) copolymer matrix for delivery of chlorhexidine and acyclovir drugs for use in the oral environment: effect of drug combination, copolymer composition and coating on the drug release rate', Dental materials: official publication of the Academy of Dental Materials, 23(4), pp. 404-409.

Varghese, S. S., Ramesh, A. and Veeraiyan, D. N. (2019) 'Blended Module-Based Teaching in Biostatistics and Research Methodology: A Retrospective Study with Postgraduate Dental Students', Journal of dental education, 83(4), pp. 445-450. 